named; and the Jannings family of Norwich, the Miss Jannings, "my relations." "To the Royal Ophthalmic Hospital my drawings of diseases of the eye for the use of the students."

The executors were his brother, Robert ffarre Dalrymple, of 2, Southwick Crescent, Hyde Park, and his brother-in-law, Thomas Bircham. The will was sworn to May 12, 1852; and probate was granted in London, May 15, 1852. The amount at which the estate was sworn is not mentioned.

His brothers Archibald and Donald were in practice in Norwich. Archibald was Assistant Surgeon to the Norfolk and Norwich Hospital; he died before 1858. Donald was alive then; he was Surgeon-Accoucheur to the Norfolk Lying-in Charity, and Proprietor of and Surgeon to Heigham Retreat.

Those beautiful paintings of diseases of the eye are still preserved in the library of the Royal London Ophthalmic Hospital.

In conclusion I must express my best thanks to Mr. Percy Flemming, who has placed his unrivalled knowledge of the history of Moorfields Hospital and its honorary staff at my disposal, in a series of extracts from his notes taken from the minutes of the meetings of the Managing Committee.

The frontispiece is reproduced from a lithograph which hangs in the Bowman Library, kindly photographed for me by Miss Blake. For leave to have this photo taken I owe a debt of gratitude to Mr. W. G. Spencer, Hon. Librarian of the Royal Society of Medicine.

\title{
TRACHOMA IN PALESTINE. ITS EPIDEMIOLOGY AND A REVIEW OF MEASURES FOR DEALING WITH IT
}

\author{
BY \\ N. Shimkin, M.D., Ph.D. \\ CHIEF OPHTHALMOLOGIST OF HADASSAH MEDICAL ORGANIZATION, \\ HAIFA, PALESTINE
}

\section{Review of Literature}

THE first information that came under my notice from a European source was the report published in 1896 by the Petrograd oculist, Dr. Th. German ${ }^{(1)}$, who had been sent by the Russo-Palestine Society on a special mission to Syria and Palestine in order to examine the state of eyes of the school children under the care of the Mission, and to adopt measures against the eye diseases.

One thousand and ninety-six Arab children were examined by Dr. German in Palestine. Thirty-eight per cent. of the children 
of the town schools and 64 per cent. of the children of the village schools were infected with trachoma. From this statement it will be seen that the Arab village schools had nearly double the number of cases of trachoma found in the town schools, and that on an average there were 51 per cent. of cases of trachoma in the Arab schools. Not without interest is his statement that of the 103 children examined by him in the German colony of Haifa there was not a single child infected with that disease. He also examined 1,228 grown up patients, viz.: 540 at Jerusalem, 367 at Bet-Lachem, and 321 in Nazareth, and of all those examined only 37 had no sign whatever of trachoma. Although the number of patients who came to the doctor for help on account of their disease does not entitle us to come to any conclusion, there is reason to believe that trachoma was widespread in the Palestinian towns to 1896 , and, taking into account the above figures with regard to school children, the incidence probably was much higher in the villages.

I have found other valuable information about the distribution of trachoma in Palestine in the reports concerning the Hebrew schools which were published for the period 1913-15.

Dr. Krinkin ${ }^{(2)}$, the Jaffa oculist, gives some interesting data in his work published in 1913 (Hebrew) "Trachoma in the Hebrew Schools of Palestine, and How to Fight Against it." Two thousand three hundred and twenty-two school children were examined by him in Jaffa, Haifa, and several Jewish colonies of Judea, and among them he found 426 cases of trachoma, i.e., 18.5 per cent. Of 110 children examined in the Jaffa kindergartens, 44 children (40 per cent.) were infected with trachoma; in the Haifa kindergartens 26 children out of 72 (36 per cent.) suffered from that disease. In the kindergartens of the Jewish colonies of Judea, such as Rehoboth and Rishon Lezion, 34-35 per cent. were infected with trachoma. The proportion of the children infected with trachoma in the elementary schools of Judea varies between 13 per cent. in Petach-Tikva and 46.6 per cent. in Rehoboth. In one of the colonies in Beer Jacob, 11 children out of 12-amounting to 92 per cent.-were infected. In the Jaffa Elementary School for girls there were 42 trachoma cases among 386 children (10.9 per cent.) whereas there were only four trachoma cases among the 350 children of the Jaffa Gymnasium, i.e., 1 per cent.

On the strength of the above facts it is evident that the percentage of trachoma in the kindergartens of the town and also of the country fluctuates between 34 per cent. and 40 per cent., whereas in the elementary schools the proportion of the trachoma cases is much higher in the country than in the town (Jaffa).

Dr. E. Auerbach ${ }^{(3)}$, who had had the children of the Haifa kindergartens under his observation in the course of several years, 
found 212 trachoma cases among 555 children, i.e., 38.2 per cent., and out of 250 children under the age of six the following incidence of infection was found:

\begin{tabular}{rrrrrrr} 
Age. & \multicolumn{9}{c}{ Number of infected. } & & Per cent. \\
1 & $\ldots$ & $\ldots$ & 59 & $\ldots$ & $\ldots$ & 23.6 \\
2 & $\ldots$ & $\ldots$ & 116 & $\ldots$ & $\ldots$ & 46.4 \\
3 & $\ldots$ & $\ldots$ & 42 & $\ldots$ & $\ldots$ & 16.3 \\
4 & $\ldots$ & $\ldots$ & 18 & $\ldots$ & $\ldots$ & 7.2 \\
5 & $\ldots$ & $\ldots$ & 12 & $\ldots$ & $\ldots$ & 4.8 \\
6 & $\ldots$ & $\ldots$ & 3 & $\ldots$ & $\ldots$ & 1.2
\end{tabular}

On the above facts he came to the conclusion that two-thirds at least of all the children affected with that disease were being infected in their early childhood.

Dr. Feigenbaum ${ }^{(4)}$ having examined 1,500 children and adults states that among the children under the age of three there were 26.8 per cent. of trachoma, among the children between eight to fourteen $=28$ per cent., fifteen to twenty $=33.9$ per cent. He also came to the conclusion "that most cases are infected very early; under the age of three."

The most comprehensive statistical material regarding the distribution of trachoma in Palestine is found in the report of the first trachoma meeting of the Jewish physicians of Palestine held in April, 1914(5). At this meeting a paper was read by Dr. Ticho in which he reported on his observations made in Jerusalem. Out of the 4,313 children examined by him in the Jerusalem schools 1,206 were infected with trachoma, i.e., 27.96 per cent. the rate fluctuating in various schools between 15.5 per cent. and 81.6 per cent. (Persian Talmud-Tora). Another paper was read by Dr. Feigenbaum in which he reported on 2,124 children examined by him in the Jerusalem schools and other institutions, where he found 533 trachoma cases $=26.46$ per cent. ; and it should be noted that this number comprised 713 children from Arab schools, 189 of which (26.5 per cent.) suffered from trachoma. Out of 553 cases there were 484 cases of active and 69 of cured trachoma. In his report Dr. Feigenbaum also gave the results of his investigations in the colonies of Judea, where he examined 1,128 persons (children and adults), 276 of whom suffered from active trachoma and 36 from cured trachoma; the total amount of trachoma cases being 312 (27.66 per cent.). Of the schools examined by him, the lowest rate of trachoma (4.5 per cent.) was found in the Hebrew Gymnasium in Jerusalem and the highest percentage in the Persian Talmud-Tora " $B$ " (44 per cent.).

In 1915 Dr. Friedenwald(6) published his monograph "The Ophthalmias of Palestine." After a comprehensive survey of the 
literature on that subject, the author reported on about 2,000 cases examined by him personally during the period June 22 to August 4, 1914. Half of the cases examined comprised only children, 54 per cent. of whom suffered from trachoma, and the percentage varied in different schools between 8 per cent. and 85 per cent. Dr. Friedenwald's report deals chiefly with Safed, Tiberias, and the colonies of Lower Galilee. His report contains also some statistics of his last examination of the Haifa school children. He also examined the Judean colonies Rehoboth and Ekron. In the former the percentage of trachoma amounted to 31.5 per cent., varying in different schools between 21 per cent. and 73 per cent. In Ekron he found among the children 43 per cent. of active trachoma which together with the cases of cured trachoma came to 71 per cent.

Of the late treatises on this subject I would mention Dr. A. Telavivi-Malchi's(7) article (published, 1918) "Das Trachom in Palaestina," dealing chiefly with reports of the above-mentioned meeting on trachoma in Jerusalem.

Finally, I should like to mention here the article published by myself ${ }^{(8)}$ in 1922 , containing the results of my investigations in the Jaffa schools (excluding the Gymnasium) during May, 1921. I examined 2,045 children of elementary schools and kindergartens. Of active trachoma there were 653 cases $=31.8$ per cent., of cured trachoma 124 cases $=6$ per cent., the total percentage of trachoma being then 37.8 per cent.

In the Lancet ${ }^{(17)}$ of September 30, 1922, Drs. Ticho and Kligler stated that the incidence of trachoma in Palestine was in inverse ratio to the age and was a disease of young children. Dr. Kligler maintains that trachoma has no acute epidemic characters. It is transmitted by direct contact during the purulent stage. The chronic stages are not so infectious.

\section{I.--Statistics}

\section{Trachoma in the Jewish Schools in I913-14}

(See Table I, Diagrams No. 1 and No. 2.)

From the above data gathered almost simultaneously by various ophthalmologists for the period of 1913-1914 a comprehensive idea may be obtained of the spread of trachoma in the Hebrew city schools as well as in the country schools. The data are shown in Table 1, the figures for Jerusalem and Judea being taken from the reports of Dr. Ticho and Dr. Feigenbaum which were read at the trachoma meeting. The figures for Jaffa were taken from Dr. Krinkin, and for Haifa, Tiberias, and Lower Galilee from Dr. Friedenwald. 
From this table we see that in 1913-14, 9,329 children were examined in the Hebrew schools of Palestine. Among them there were 2,423 cases of active trachoma (26 per cent.), 188 cases of cured trachoma (2.7 per cent.), the total number of children infected by trachoma being 2,611 (28. $\tau$ per cent.). In the towns the percentage of active trachoma varies between 23.3 per cent. in Haifa, 26.2 per cent. in Jerusalem, and 83.2 per cent. in Tiberias (202 m. below sea-level). In the colonies of Judea the percentage of active trachoma came to 24.5 per cent., and in the colonies of Lower Galilee 38.7 per cent.

\section{Trachoma in the Hebrew Schools in I9I8-I9}

\section{(Table I, Diagrams No. 1 and No. 2.)}

In the middle of 1918 all the medical work among the Jewish population of Palestine was transferred to the American Medical Zionist Unit, called afterwards "Hadassah" Medical Organization (H.M.O.)," which organization still carries on its work. A special commission of medical men was appointed by the Zionist Executive Committee for the investigation of the distribution of both malaria and trachoma in Palestine. The work began at the end of 1918 and was concluded at the beginning of 1919 .

The oculist of the H.M.O., Dr. Krimsky, examined the spread of trachoma in the Hebrew urban and rural schools. He examined 8,506 children, 3,465 (i.e., 40.7 per cent.) of whom suffered from active trachoma, and $1,056=12.4$ per cent. from cured trachoma; the total of trachoma cases being $4,521=53.1$ per cent. In the towns the percentage of active trachoma varied: in Jerusalem 21.6 per cent., Haifa 49 per cent., Safed 55 per cent., Tiberias 78.3 per cent. As to Jaffa the percentage of active trachoma was indicated as high as 64.8 per cent., but only 182 children had been examined. It is probable that, had all the children of Jaffa been examined, the percentage of trachoma would have been lower, but still that percentage must have been relatively high, since my observation made in May, 1921 (after a year's experience in the schools) showed no less than 31.8 per cent. of active trachoma. On an average there was 34.5 per cent. of active trachoma in the towns. In the colonies the percentage of active trachoma varied between 45 per cent. in Samaria, 46 per cent. in Lower Galilee, 49 per cent. in Judea, and 64.5 per cent. in Upper Galilee, the average percentage of active trachoma in the colonies being then 50.6 per cent. On comparing the figures for 1913-14, when 9,329 were examined, with those for 1918-19 when 8,506 pupils were examined, it is seen that in 1913-14 there was 26 per cent. of active trachoma as against 40.7 per cent. in 1918-19, the total 
percentage of trachoma (including cases of cured trachoma) being 28 per cent. in 1913-14 against 53.1 per cent. in 1918-19 (see Table 1, Diagrams No. 1 and No. 2). This enormous spread of trachoma in the course of five years may be easily explained by the precarious position of the Palestine population in general and by the sufferings of the Jewish population during the war in particular. The distressed condition on the one hand and the lack of medical assistance on the other hand contributed greatly to the spread of trachoma. The population of the rural districts suffered much more than that of the towns. With the outbreak of war most colonies were deprived of every medical assistance, and consequently the percentage of active trachoma in the colonies was one and a half times greater than in the towns.

\section{Trachoma in the Hebrew Schools in 1923-24}

(Table I, Diagrams No. 1 and No. 2.)

The fight against trachoma gradually extended. The systematic trachoma crusade organized by the Hadassah Medical Organization began in the schools of Jerusalem 1918, in the Jaffa schools 1919 , in Haifa 1920 , in Safed at the beginning of 1921 , and in Tiberias at the end of 1921. It was not until the early months of 1924 that the fight against trachoma was begun in the Jewish colonies. Up to that time the colonies had been visited by oculists at intervals only.

For the uniform indication of the types of trachoma the following scheme was agreed to:

First Stage.-Trachoma granules cover the retrotarsal fold of the upper or lower lid, or are-found in the plica semilunaris, or on the caruncle.

Second Stage.- Trachoma granules cover the conjunctiva of the tarsus, or are found in the tarsus itself.

Third Stage.-Is recognized by hypertrophic scars of the conjunctiva.

Fourth Stage.-Cured Trachoma.

Complicated trachoma (pannus, trichiasis), defective sight, blindness, various forms of conjunctivitis and other eye diseases are shown in separate columns.

\section{Number of School Children and of Medical Staff}

The H.M.O. has now about 14,000 children under its control. seven oculists are charged with the treatment of eye diseases, two of whom reside in Jerusalem, one at Jaffa, one at Haifa, one at Tiberias, one at Safed, and one is appointed for systematic inspection in the colonies. There are also in the colonies of Lower Galilee eight physicians in charge of the general medical 
work who superintend the work of the nurses (Lower Galilee 2, Upper Galilee 3, Samaria 1, Judea 2). In addition to the work in the schools there are ophthalmic clinics with 150 to 300 and even more daily attendances. In addition to physicians specialized in their work there are employed in the schools twenty eye nurses under direct medical control (in Jerusalem 10, Tel-Aviv-Jaffa 5 , Haifa 2, Tiberias 3). In the colonies ten nurses are employed (Judea 3, Samaria 2, Lower Galilee 5). Nurses also work in the colonies and give the population of the colonies assistance under the instructions of the doctor. The sum spent by the H.M.O. for the treatment of eye diseases in the schools amounted to 3,383 L.E. in 1923-24.

According to the system in use the doctors inspect the schools at the beginning of the scholastic year. Every child has its trachoma schedule. The inspecting doctor diagnoses and prescribes accordingly, the eye nurse being charged with the treatment according to the doctor's prescriptions. Such an inspection takes place not less than once in two months, kindergartens and schools where there is much trachoma being inspected as often as once a month. Children suffering from acute conjunctivitis are excluded from school and sent to the clinic for treatment. Children infected with follicular trachoma are also sent to the clinic for treatment and operation (expression of granules), and are only allowed to attend school again after complete cure. Follicular cases of trachoma should be excluded from school. No child is admitted to school in the course of the scholastic year without a doctor's certificate regarding the state of its eyes. The treatment is performed by nurses every day in special rooms in the schools. The most simple methods of treatment are being employed. Massage with a cotton applicator moistened in hydr.-oxicyanat. $(1: 2,000)$; massage with unguent. flav. 2 per cent.; instillation of protargol 5 per cent.; argent. nitr. 1 per cent.; zinc sulph. 0.5 per cent.; copper sulphate (crystal and 5 per cent. solution). In every complication of the cornea the child is excluded from school and sent to the clinic for treatment. It is not only the treatment of disease, but the prophylactic treatment of the eye that gives so much work to the nurses. All pupils are being treated-especially in summer-with a zinc solution of 0.5 per cent. or a 3 per cent. protargol solution. Experience has shown that where prophylactic treatment has been employed the percentage of acute inflammations (conjunctivitis acuta) which used to spread epidemically in Palestine in the summer months, has perceptibly diminished. Prophylactic treatment is particularly important in schools where trachoma-infected children come in contact with uninfected ones. If possible, infected children are separated from healthy ones. Separate kindergartens are arranged for trachoma-infected children. 
Trachoma in Palestine

DIAGRAM No. 1.

TRACHOMA IN JEWISH SCHOOLS IN PALESTINE

IN TOWNS AND Colonies IN THE YeARS

1913-14, 1918-19, and 1923-24.

(For total number of cases see Table No. 1.)

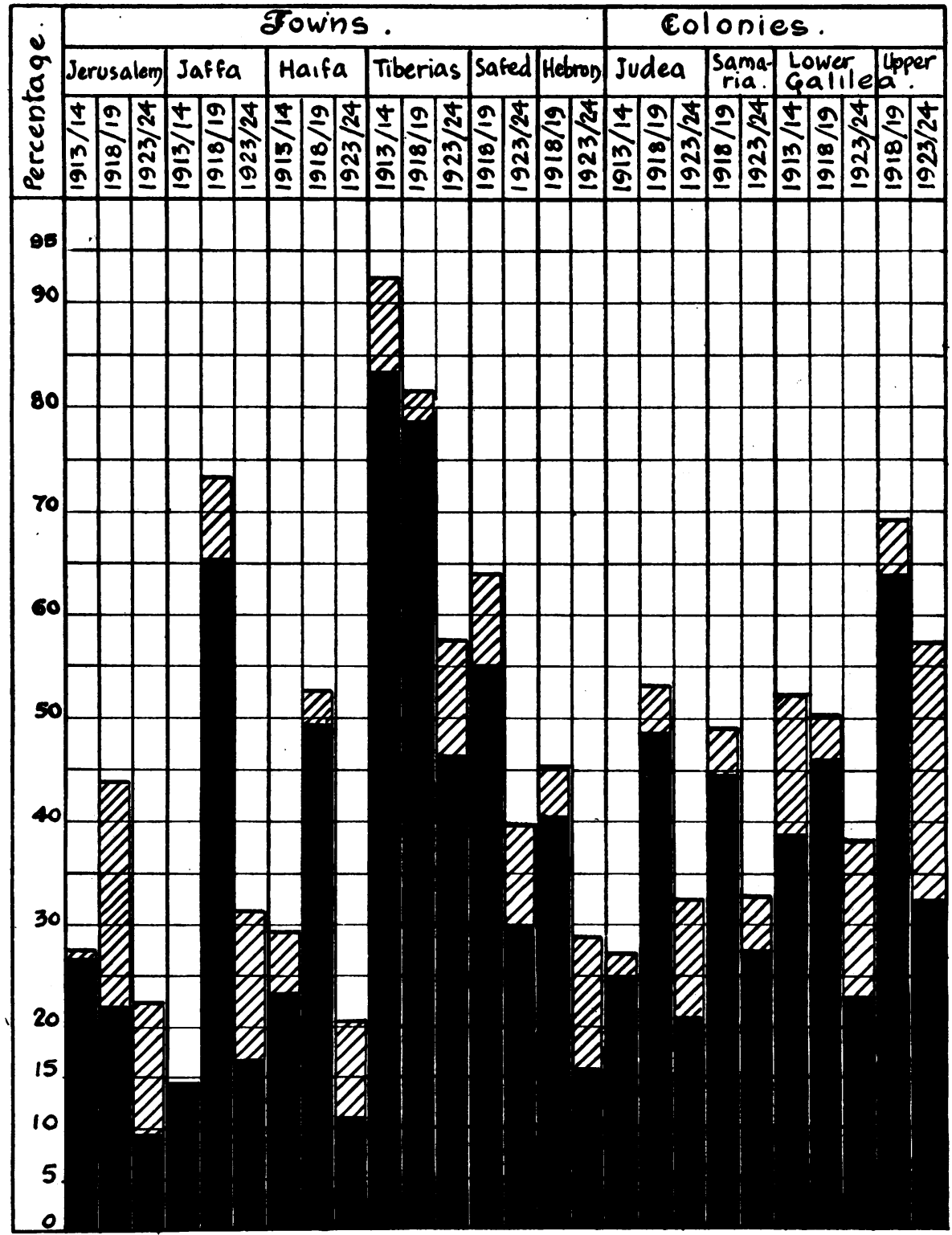

Trachoma aclive . Trachoma cured 

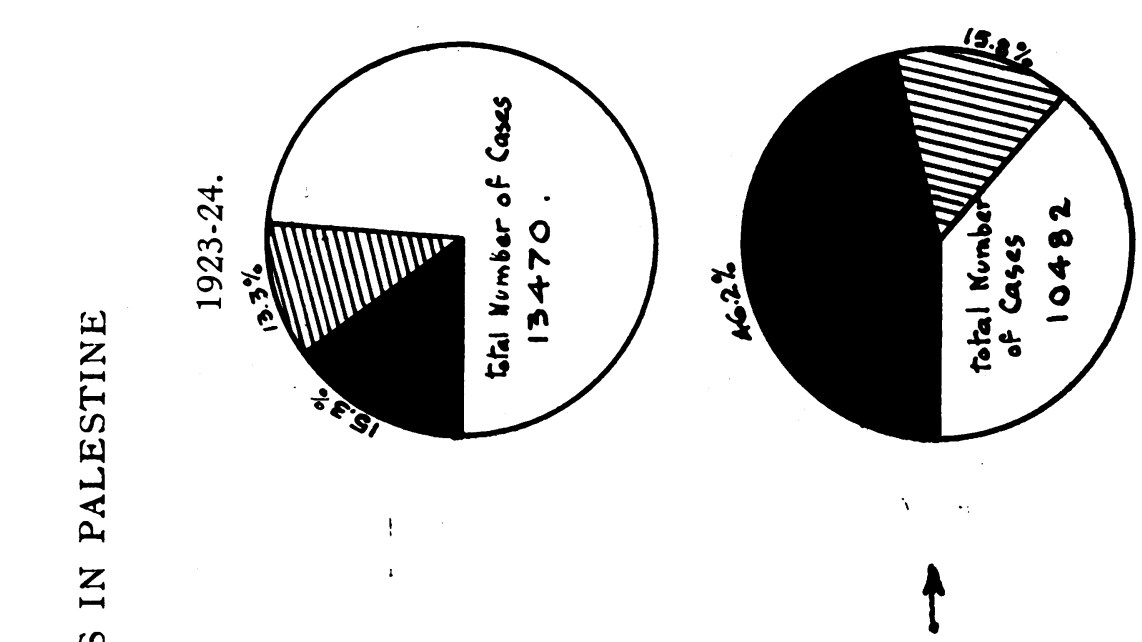

告

ง
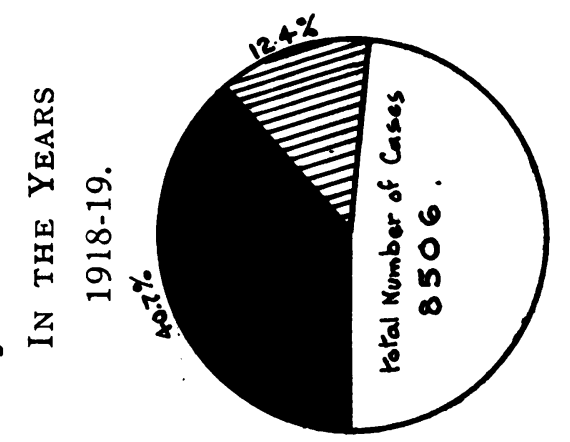

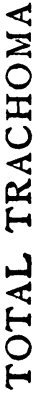
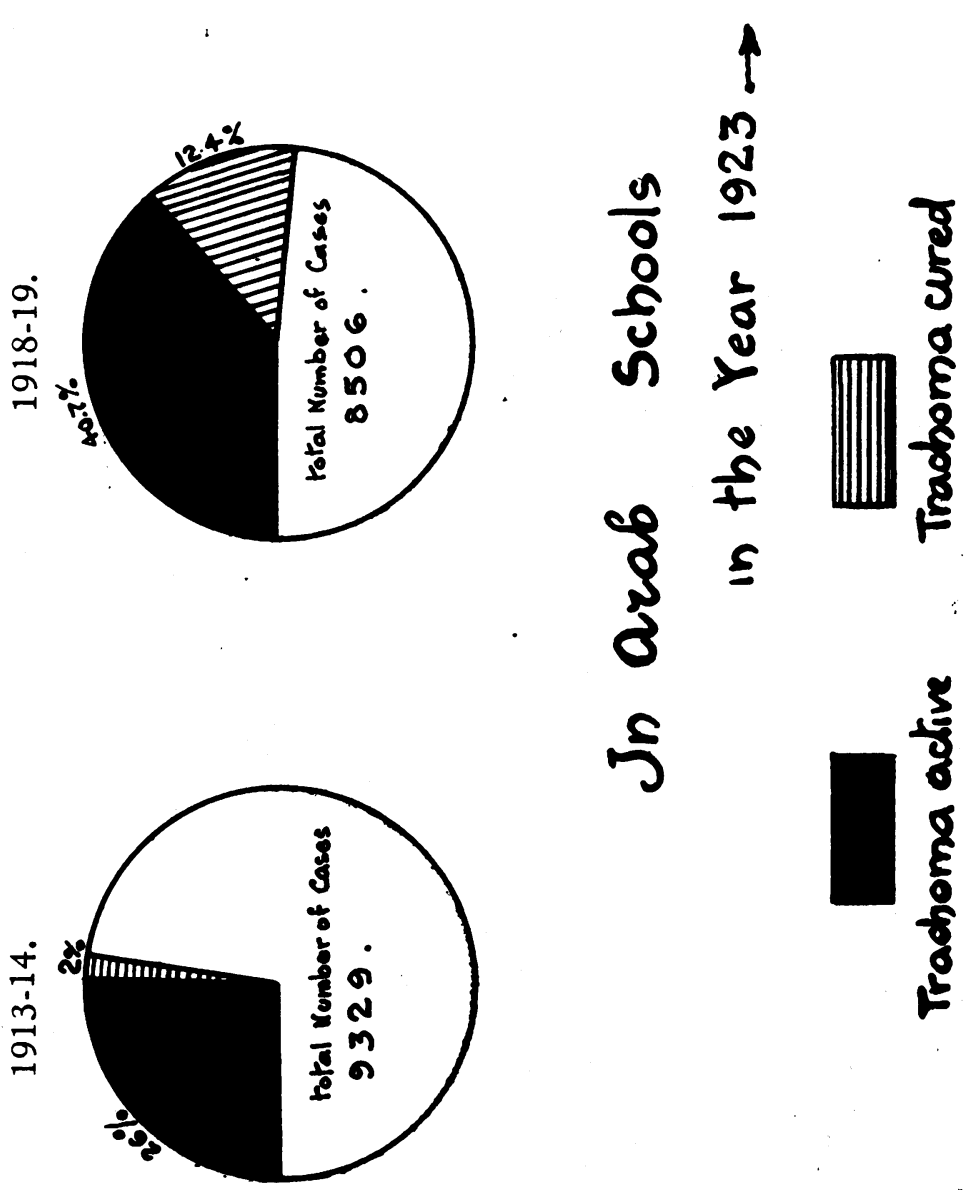

9 \&

$\frac{2}{3}$
0
5
5

No

¿ $\backsim$

$\sum \underset{\sim}{M} \infty$

\&

点

Z

3

2

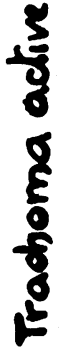


Where there is no possibility of separating infected children in special groups or classes, special desks are assigned to them, every teacher being provided with a list of the trachoma-infected pupils. In kindergartens with much trachoma, games where the children hold one another by the hand are prohibited. All teachers are instructed that any secretion coming from the eye may be contagious.

At every inspection the doctor makes a detailed statement of all the eye diseases. On every schedule the date of inspection, the diagnosis and the method of treatment are stated. Detailed daily reports regarding the children under treatment are made by the nurses. On an average 300 to 500 children (dependent on the number of the trachoma cases in any particular place) are treated by one nurse. All the inspection reports made in the schools of Judea are sent to the district oculist in Jerusalem. Those made in the schools of Samaria, Upper and Lower Galilee, and Emek Jizrael are sent to the district oculist at Haifa. These reports containing all the remarks of the district oculists have to be sent to the Central Administration of the H.M.O. in Jerusalem, where all the statistical material is prepared. It is this statistical material received from the Central Administration of the H.M.O. that has enabled me to compile Table 1 and Diagrams No. 1 and No. 2, which show the number of trachoma cases in the Hebrew schools during the scholastic year 1923-24.

\section{Trachoma in the Hebrew Schools in 1923-24}

In the above-mentioned year 13,470 children had been examined, $2,059=15.3$ per cent. of whom suffered from active trachoma and $1,754=13.3$ per cent. from cured trachoma, the total amount of trachoma cases being then $3,873=28.6$ per cent. In the towns there were $1,656=14.5$ per cent. of active trachoma, and $1,497=$ 13.1 per cent. of cured trachoma. In the colonies there were 469 cases $=22.3$ per cent. of active trachoma and $257=12.2$ per cent. of cured trachoma. In consequence of the growth of the number of children in the schools of Jerusalem, Tel-Aviv and Haifa caused by the unceasing stream of immigration the figures quoted do not convey any precise idea of the success of the trachoma crusade, whereas the statistical figures concerning Safed, Tiberias, and the Jewish colonies which have remained almost untouched by the immigration, and have had the same population as before the war, will throw some light on the decline of trachoma.

On comparing the spread of trachoma for some years past we learn that in Safed there were 55 per cent. of active trachoma in 1918-19, and 29.6 per cent. in 1923-24. In Tiberias there were 83.2 per cent. of active trachoma in 1913-14, 78.3 per cent. in 1918 19 and 46 per cent. in 1923-24, which means that two and a half 
years of systematic treatment caused a 50 per cent. fall in trachoma. In the colonies there were in 1913-14, 27.4 per cent. active trachoma, in 1918-19, 50.6 per cent., and only 22.3 per cent. in 1923-24. The last figures show that even in such places as the Jewish colonies where trachoma has not been so systematically treated, the percentage of active trachoma fell by more than half. In order to convey a precise idea of the results of the trachoma crusade which were gained in the Hebrew schools it would be interesting to compare the absolute figures of the spread of active trachoma as well as of cured trachoma during the following quinquennia : 1913-14, 1918-19, 1923-24 as represented in Table 1 and Diagrams No. 1 , No. 2 .

\begin{tabular}{|c|c|c|c|c|c|c|}
\hline \multicolumn{4}{|c|}{ Years } & $1913 / 14$ & $1918 / 19$ & $1923 / 24$ \\
\hline Active & achoma & $\ldots$ & $\ldots$ & 2,423 & 3,465 & 2,059 \\
\hline Cured & , & $\ldots$ & $\ldots$ & 188 & 1,056 & 1,754 \\
\hline
\end{tabular}

On comparing these absolute figures we see that active trachoma in 1923-24 was one and a half times less than in 1918-19. The cases of cured trachoma in 1923-24 exceeded those of 1918-19 by one and a half times and by nine times the number shown for 1913 .

The decline of trachoma is still better illustrated by the figures taken from particular towns.

\begin{tabular}{lccc}
\multicolumn{1}{c}{ CASES OF } & ACTIVE & TRACHOMA & IN \\
& $1913-14$ & $1918-19$ & $1923-24$ \\
Jerusalem & 1,690 & 752 & 511 \\
Haifa & 107 & 286 & 116
\end{tabular}

The above figures show clearly that since 1920 , when the treatment of trachoma began, the number of trachoma cases fell by two and a half times. From the above figures for Jerusalem it follows that the number of trachoma cases in 1923-24 fell by three times when compared with 1913-14 and by one and a half times when compared with 1918-19. This comparison is much the more important as it clearly shows how active trachoma may be successfully combated particularly in its first and second stages. When the third stage of trachoma is reached the fight against it is much. more difficult and its treatment requires months and even years of constant work.

The above figures also show that the number of active trachoma cases does not rise, notwithstanding the annual addition of new trachoma cases in our schools. The continual influx of new trachoma cases into our schools comes through two channels: (1) through immigration; (2) through the family. Together with 
the healthy children coming from Russia, Poland, Austria, etc., we get a considerable number of diseased ones from Persia, Yemen, Kurdistan, and Caucasia. Most children infected with trachoma, however, come from the families of the original Sephardim and also Aschkenasim who have lived in Palestine for a long time, and not only got infected themselves with trachoma through association with the Arab population but also transferred that disease to their children. Finally, let it be said that in many families, where the

DIAGRAM No. 7.

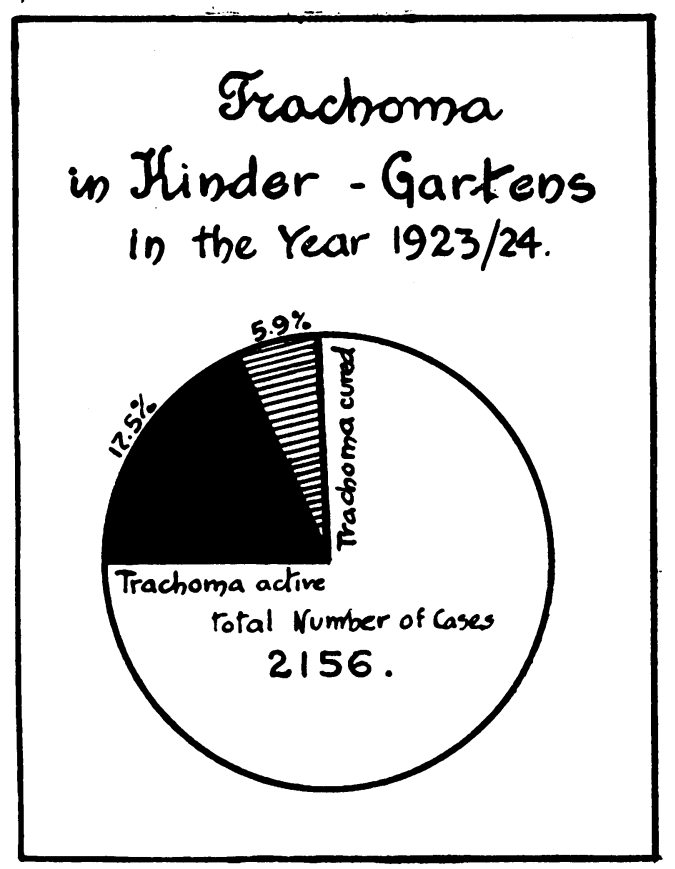

parents do not suffer from that disease, trachoma is being spread through the Arab servant, or, as it is the case in the Jewish colonies, through close association with the Arab population, the latter, as we shall see being more infected with trachoma than the Jewish population.

The data of the Hadassah Medical Organization which are based on the investigations made in the kindergartens (chiefly attended by children three to five years old) show that out of 2,156 children there were 33 . (1.5 per cent.) of trachoma suspects; 14 cases ( 0.65 per cent.) of trachoma in the first stage, 98 cases ( 4.5 per cent.) of trachoma in the second stage, 234 ( 10.8 per cent.) of trachoma in the third stage, and 127 cases (5.9 per cent.) of trachoma in the fourth stage (see Diagram No. 7 ). 
In other words, there were 506 (23 per cent.) children at the age of three to five infected with trachoma, among whom there were $12 \tau$ children with trachoma in the fourth stage (cured trachoma) and these must have been infected at the age of two, and long before having entered the kindergarten.

These results correspond with the data contained in the review of literature, and again verify the fact that trachoma in Palestine is a disease of the child in its earliest age, the infected parentusually the mother-being responsible for its spread.

Suppose that no less than 400 children with active trachoma enter the schools every year, this means that in the last five years there have been 2,000 new cases of active trachoma. If we add thereto the 3,465 cases of active trachoma in 1918-19, we should have 5,465 cases of active trachoma if there had been no systematic treatment. Now we have only 2,050 cases.

The following Table No. 2 shows that through the treatment in the schools trachoma is becoming less.

TABLE II.

TRACHOMA IN SCHOOLS IN PALESTINE.

In Towns: Jerusalem, Haifa, Safed, and Tiberias IN THE YeAR 1923/24.

Showing Distribution according to Age.

\begin{tabular}{c|c|c|c|c|c}
\hline Age & Examined & $\begin{array}{c}\text { Active } \\
\text { Trachoma }\end{array}$ & $\begin{array}{c}\text { Per } \\
\text { cent. }\end{array}$ & $\begin{array}{c}\text { Cured } \\
\text { Trachoma }\end{array}$ & $\begin{array}{c}\text { Per } \\
\text { cent. }\end{array}$ \\
\cline { 1 - 5 } $3-6$ & 1,074 & 185 & 17.2 & 44 & 4.1 \\
$6-7$ & 1,165 & 208 & 17.8 & 184 & 15.8 \\
$7-8$ & 1,126 & 202 & 17.9 & 144 & 12.8 \\
$8-9$ & 1,081 & 166 & 15.3 & 130 & 12 \\
$9-10$ & 834 & 102 & 12.2 & 112 & 13.4 \\
$10-11$ & 769 & 113 & 14.7 & 99 & 12 \\
$11-12$ & 501 & 47 & 9.6 & 64 & 12.7 \\
$12-13$ & 420 & 31 & 7.4 & 36 & 8.6 \\
$13-14$ & 237 & 23 & 9.7 & 21 & 4.6 \\
$14-15$ & 315 & 17 & 5.4 & 19 & 6 \\
$15-16$ & 56 & 2 & 3.6 & 5 & 8.9 \\
$16-17$ & 42 & - & - & 1 & 2.4 \\
$17-18$ & 36 & - & - & 2 & 5.5 \\
$18-19$ & 27 & - & - & 1 & 4 \\
\hline Total & 7.683 & 1,096 & 14.26 & 862 & 11.2 \\
\hline
\end{tabular}

This table refers to children in the kindergartens aged from three to six, and in various elementary schools and gymnasia aged from six to eighteen. The total number of school children in Jerusalem, Haifa, Safed, and Tiberias is 7,683 .

These results show us that the percentage of trachoma is in inverse ratio to the age of the children, and the younger the 
children are the higher is the percentage of trachoma, and the longer the children attend school the lower is the percentage of active trachoma. We find the maximum of active trachoma among children between three and ten years of age, and between six and ten years we find the maximum of cured trachoma. Beginning with the age of ten there is a decline in the percentage of active trachoma and at the age of three to eight, i.e., the first years of the child attending a school there is an increase in the percentage of active trachoma. In other words, the school does not in the least contribute to the spread of trachoma and cannot be the source of contagion; provided that prophylactic and systematic treatment is employed.

P. Wibaut and W. H. Smit ${ }^{(9)}$ came to the same conclusion, namely, that the family and not the school is responsible for the spread of trachoma in their article "La lutte contre le trachome à Amsterdam dans les dernières années."

Table No. 2 and Diagrams Nos. 3 and 4 clearly show that the earlier treatment begins the quicker the disease disappears.

\section{Trachoma in Arab Schools}

The data regarding trachoma in Arab schools have been taken by me from the Annual Report of the Department of Health of the Palestine Government for the years 1921, and 1922 and 1923. In the report for the year 1921 it is stated that "Trachoma is by far the most important disease among school children." The P.M.O. of the Ophthalmic Hospital found a greater percentage of this disease in the schools of Southern Palestine than in those of Northern Palestine, in some of the former as many as 97 per cent. were infected. The statistics showed an average of 74 per cent. infected in the whole country while 15 per cent. suffered from defective vision. In the report for the year 1923 the statistics show a total of 10,480 school children examined among whom were 6,497 cases of trachoma, i.e., 62 per cent. Of this figure 7.5 per cent. were Stage I, 31 per cent. Stage II, 36 per cent. Stage III and 25.5 per cent. Stage IV. Therefore from among all the children examined there were 4,840 cases of active trachoma (Stages I, II and III), and 1,657 cases of cured trachoma (Stage IV), i.e., 46.3 per cent. and 15.7 per cent. respectively (see Diagram No. 2). Comparing these figures with those for the Jewish schools for the year 1923-1924 it is seen that the number of cases of active trachoma in the Arab schools is three times greater than in the Jewish schools. If, however, we compare the figures for the Arab schools for the year 1923 with those for the Jewish schools in the year 1918-1919 there is very little difference, namely, 6 per cent. This is arcounted for by the fact that until systematic 


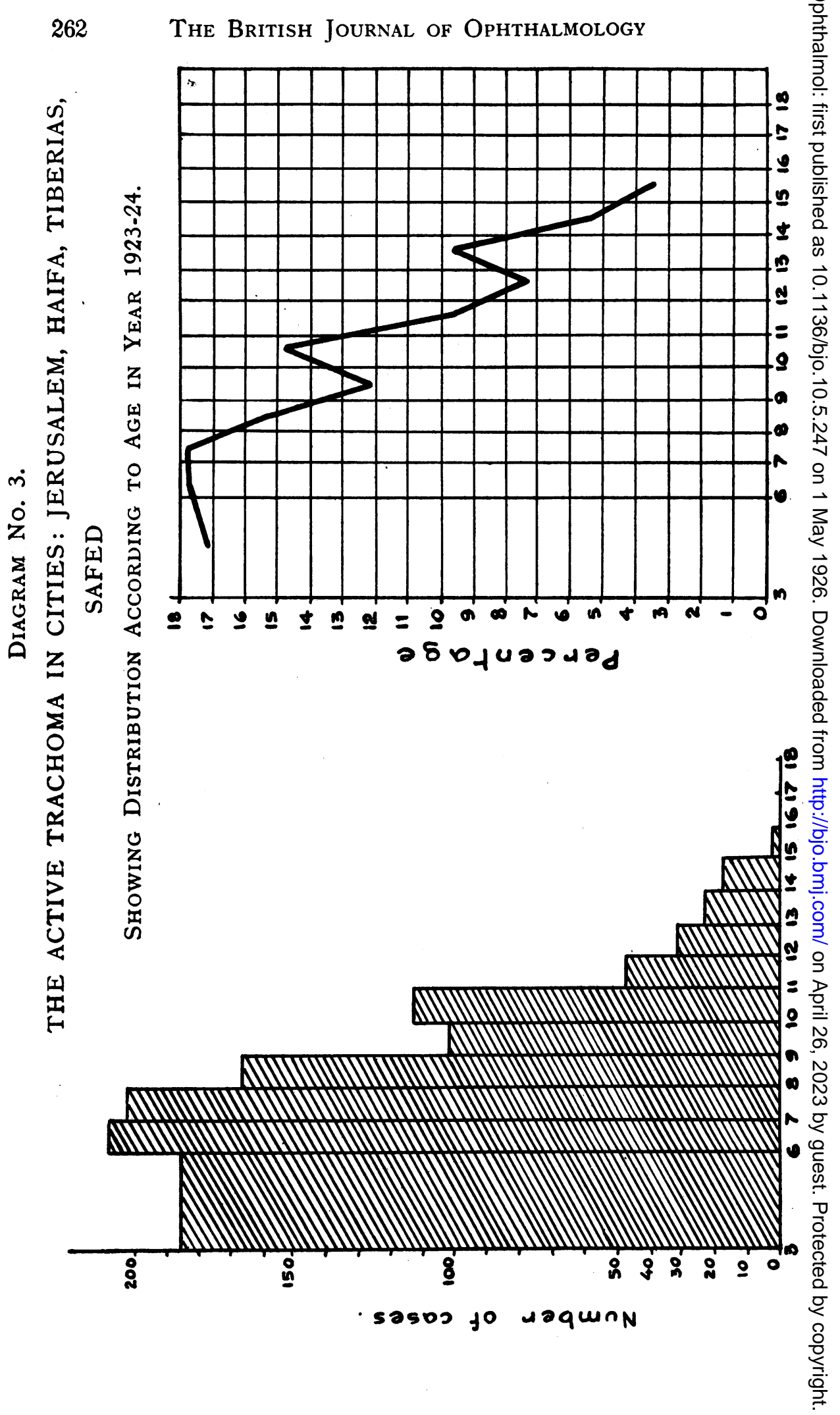




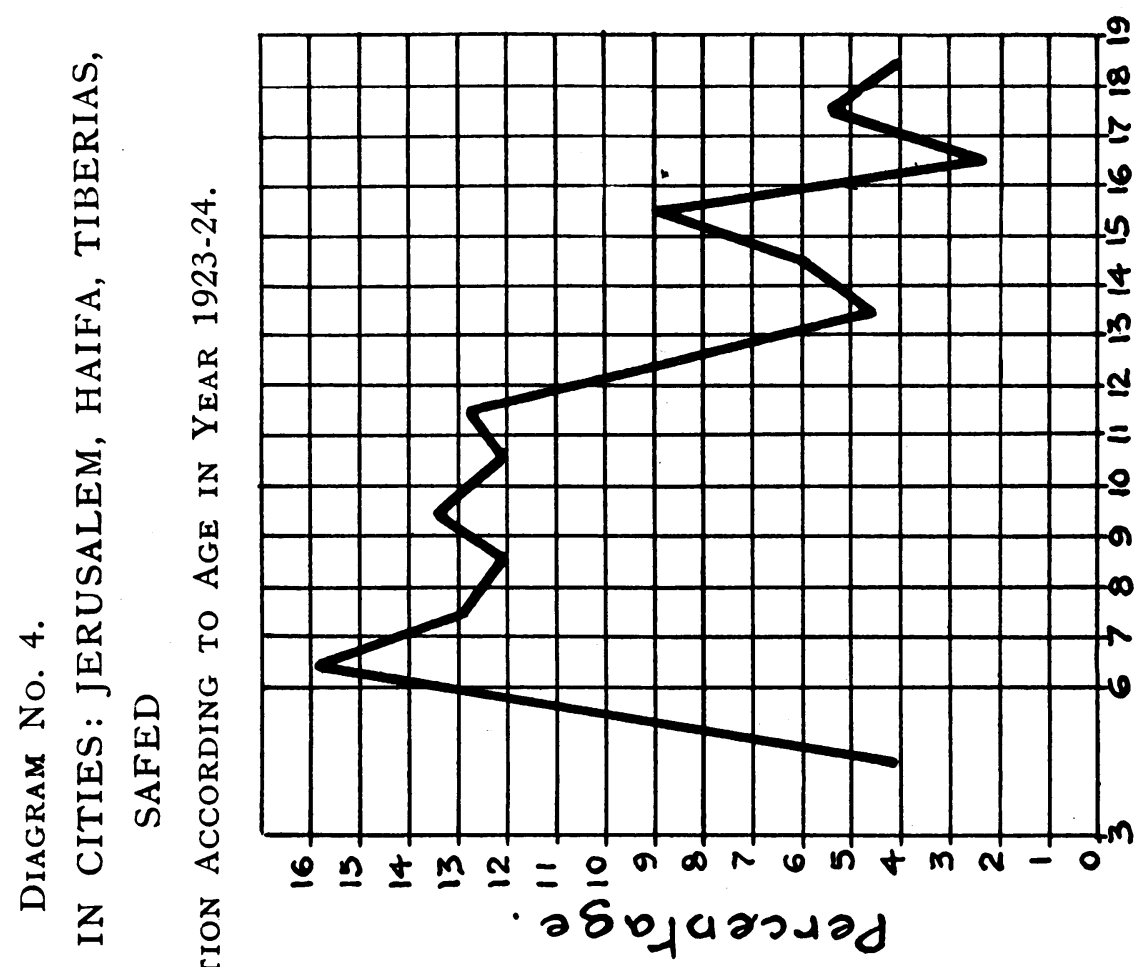


treatment was instituted the percentage of active trachoma in Jewish schools was 40.7 per cent. This latter comparison is of very great importance because by systematic treatment the percentage of trachoma in Arab schools can be reduced as it has been in Jewish schools. From the figures given above it is seen, however, that in the year 1921 the percentage of trachoma was 74 per cent. and two years later in 1923 it had fallen to 62 per cent., a reduction of 12 per cent. The percentage of children suffering from defective vision was reduced during the same period from 15 per cent. to 5.3 per cent. During these three years of work in schools the Government was busy training special personnel. Special courses of ophthalmic training were provided for medical officers. This was also done in the cases of nurses where the lack of such, properly trained in ophthalmic work, was greatly felt. The assistance of teachers in schools was also enrolled and they were taught the more elementary parts of treatment. Taking all this into consideration very good results have been obtained in a comparatively short time and under none too favourable conditions.

All the schools do not suffer to the same extent from trachoma. According to statistics for January and February, 1924, which I have obtained from the P.M.O. Ophthalmic Hospitals (Dr. Thompson) the percentage of trachoma in Government schools in the south of Palestine was as follows:

$$
\begin{array}{lllllr}
\text { Beersheba } & \ldots & \ldots & \ldots & \ldots & 88.7 \text { per cent. } \\
\text { Ramleh } & \ldots & \ldots & \ldots & \ldots & \text { 70 per cent. }
\end{array}
$$

In the north of Palestine the percentages were:

$$
\begin{aligned}
& \begin{array}{llllll}
\text { Nazareth } & \ldots & \ldots & \ldots & \ldots & 43.1 \text { per cent. }
\end{array} \\
& \begin{array}{llllll}
\text { Haifa } & \ldots & \ldots & \ldots & \ldots & 45.8 \text { per cent. }
\end{array} \\
& \begin{array}{lllllll}
\text { Acre } & \ldots & \ldots & \ldots & \ldots & \ldots & 22 . \tau \text { per cent. }
\end{array}
\end{aligned}
$$

These figures include Stage IV trachoma. These figures again emphasize the fact that the people in the north of Palestine suffer less from trachoma than those in the south.

\section{Trachoma among the Adult Population in Palestine}

The incidence of trachoma among the adult population of Palestine cannot be fixed exactly but in general the figure may be taken as approximating to that among the children in the schools. There is no doubt that the rural population suffer more from trachoma than the urban population. This applies to both Jew and Arab. In the towns generally a more educated population exists, sanitation is better and medical assistance is more easily obtained. In the Department of Health's Annual Report for 1922 the statement is made that "it is from the schools that accurate 
detailed information regarding the amount of eye diseases has been obtained and it is found that $9 \tau$ per cent. of the population of Southern Palestine have trachoma ; 69 per cent. in Nablus; and in some of the schools of Acre in Northern Palestine not more than 15 per cent." This high incidence of trachoma, especially in the south of Palestine, is very serious as it brings in its train many serious conditions of the eyelids and the cornea. During a period of ten months while working in the vicinity of Nablus and Ramleh the Government Travelling Ophthalmic Hospital dealt with 4,381 persons and 90.6 per cent.. of these had trachoma and 31 per cent. of these cases of trachoma were suffering from trichiasis.

\section{II.-The Epidemiology of Trachoma in Palestine}

Reviewing the prevalence of trachoma in the Arab schools and among the adult Arab population I have indicated more than once that the south of Palestine is more affected by trachoma than the north. This diminution of the prevalence of trachoma from south to north of Palestine is not without a definite cause. First of all, it refutes the idea that the race plays any rôle as a predisposing factor in the acquiring of trachoma. While the population of Palestine is almost homogeneous (Arabs-Moslems 78.03 per cent., Arabs-Christians 9.64 per cent., and Jews 11.06 per cent. of the total population), yet the difference in the prevalence of trachoma is quite marked in spite of the small size of the country (the south border is $31^{\circ}$ N.L., the northern border is $33^{\circ} 10^{\prime}$ N.L.). Race predisposition to trachoma has been long ago denied (Axenfeld $\left.{ }^{(10)}\right)$, also there is neither climate nor country that is "immune" to trachoma (Axenfeld ${ }^{(10)}$, Stanculeanu ${ }^{(11)}$, Paparcone ${ }^{(12)}$. Under certain living conditions, every race and every nation, independent of the degree of latitude or longitude it resides in, can be affected by trachoma. As an illustration I can cite the prevalence of trachoma among the German settlers of Haifa and those of Russia - on the shores of the river Volga. In the review of literature the fact was mentioned that Dr. German in 1896 found not a single infection with trachoma among 103 children of German settlers in Haifa; at the present time there are only two to three families among the German settlers of Haifa affected with trachoma, while the trachoma incidence among the German schools in Russia-Volga districts-is very high, more than 20 to 24 per cent. (Scheffer $\left.{ }^{(18)}\right)$. Altitude likewise is not a factor in immunity against trachoma. It suffices to mention from the review of literature in the year 1913-14 that in Jerusalem-830 metres above sea-level--the trachoma prevalence in some schools reached 81 per cent., and in Tiberias-202 metres under the sea-level-the trachoma prevalence was 83 per cent. (1913-14). Undoubtedly, the main factor in the spread of trachoma is the sanitary conditions 
under which the population lives. Where there is much uncleanliness and dirt-there is also prevalence of trachoma. Among the Jewish population we find the largest percentage of trachoma in the schools frequented by children of the type of population resembling in habits the native population or Arabs (Sephardic, Jemenite, and Persian Jews). This condition is clearly brought out by the accompanying table, giving the comparative incidence of trachoma among the various types of the Jewish population.

\begin{tabular}{|c|c|c|c|c|}
\hline $\begin{array}{l}\text { Name of Town } \\
\text { or Colonies }\end{array}$ & $\begin{array}{c}\text { Type of Jewish } \\
\text { population }\end{array}$ & $\begin{array}{l}\text { No. of Children } \\
\text { examined }\end{array}$ & $\begin{array}{l}\text { No. of cases of } \\
\text { Active Trachoma }\end{array}$ & $\begin{array}{l}\text { Per } \\
\text { cent. }\end{array}$ \\
\hline $\begin{array}{l}\begin{array}{l}\text { Rishon l'Zion } \\
\text { Rehoboth } \\
\text { Khudera }\end{array} \\
\begin{array}{l}\text { Jerusalem } \\
\text { Haifa \& Alliance } \\
\text { Judea } \\
\text { of }\end{array}\end{array}$ & $\begin{array}{l}\text { Jemenite } \\
\quad, \quad \\
\text { Persian } \\
\text { Sephardic } \\
\text { Aschkenasim }\end{array}$ & $\begin{array}{r}19 \\
41 \\
16 \\
32 \\
333 \\
105\end{array}$ & $\begin{array}{r}14 \\
30 \\
14 \\
13 \\
91 \\
8\end{array}$ & $\begin{array}{r}73.6 \\
73.1 \\
87.4 \\
40.6 \\
27.3 \\
7.6\end{array}$ \\
\hline
\end{tabular}

Remark: See also Table I. Jerusalem, Haifa and Colonies in Judea.

As far as the sanitary conditions of the Arab population in the villages are concerned, it is only necessary to see their mud huts without adequate light or ventilation, to see the whole family lying on the dirty floor or sleeping on unwashed and unclean bedding, to see the children dirty and uncared for, with pus discharging from their eyes, beset by multitudes of flies. It is sufficient to see this picture only once to realize how easy is the spread of any contagious disease among a people living under such conditions. Although the causative virus of trachoma has not yet been discovered, it has been, however, proved by a considerable number of workers that trachoma is a contagious disease, spread by direct or indirect contact. Under the conditions the Arabs live in, the spread of disease by direct contact is a constant factor. Flies, as it has been proved by experiments (Nicolle, Guénod and G. Blanc $\left.{ }^{(13)}\right)$, undoubtedly play a rôle in the spread of trachoma (indirect method of contagion). Since the trachoma infection is both virulent and contagious during the whole active period of the disease, the diluted virus exists in the tears of the trachoma patient, and the smallest wound of the conjunctiva can serve as an entrance gate for the trachoma virus (Nicolle, Guénod ${ }^{(13)}$ ), it is easy to understand why trachoma spreads to such a large extent in Palestine. Besides, trachoma is a chronic disease, and in the absence of proper treatment it lasts for years. In the course of the disease children come in direct contact with parents sick with trachoma, sleep in the same bed, use the same towel or washbasin as the sick parents do. They are thus bound to become infected with the disease. The climate of Palestine favours the 
development of trauma of the conjunctiva and facilitates the entrance of the trachoma virus; also through constant irritation of the diseased conjunctiva it causes increased lacrymation and discharge of diluted trachoma virus.

Speaking of the trauma of the conjunctiva due to the climate of Palestine, it is necessary to consider not only the strong. radiation of the sun, the temperature, the amount of rains, but also the geological character of the soil of Palestine and her water supplies. The strong radiation of the sun's rays causes thermal and light trauma to the conjunctiva. The conjunctiva of the sclera in the palpebral fissure under constant action of the rays of the sun is subject to burns, which clinically manifest themselves as hyperaemia and oedema of this portion of the conjunctiva. This "conjunctivitis solaris" like any other irritation of the conjunctiva calls forth increased lacrymation.

As to the geological character of Palestine: the soil is mainly of limestone formation; the coastal plain is covered by sand dunes and to the south of Beersheba begin the sands of the Sinai desert. In the summer drought the roads and trees are covered with limestone dust. The lightest wind carries a cloud of dust which covers the eyelashes and penetrates into the eyes, causing both mechanical and chemical trauma. The sand of the dunes to the south and that of the Sinai desert also injures the conjunctiva. The summer heat, by causing the working people frequently to wipe the sweat from face and eyes with dirty hands or handkerchiefs, also helps in the inclusion of the trachoma virus into the traumatized conjunctiva.

Besides these forms of conjunctival trauma, there exists in the summer time a form of acute conjunctivitis of bacterial origin, which is also affected by the climate. In my paper: "Les maladies des yeux a Caiffa"(14) I showed that this acute conjunctivitis has a uniform character throughout Palestine, is independent of altitude, latitude or longitude, but depends upon the temperature and especially the amount and distribution of rainfall. The largest number of cases of acute conjunctivitis is found during months when the temperature is highest and the largest number of Koch-Weeks infections is found after there has been no rain for about three months.

The attached Diagrams No. 5 and No. 6 prepared by Dr. E. Krause, the bacteriologist of the Haifa Hospital of the Hadassah Medical Organization, on the basis of 2,444 bacteriological examinations of the material from the eye clinic during the years of 1922,1923 , and 1924, give a clear picture of the causes of the acute and chronic conjunctivitis. These causative factors are characteristic of the whole country, hoth as to the time of their appearance and as to their percentage relationship. 


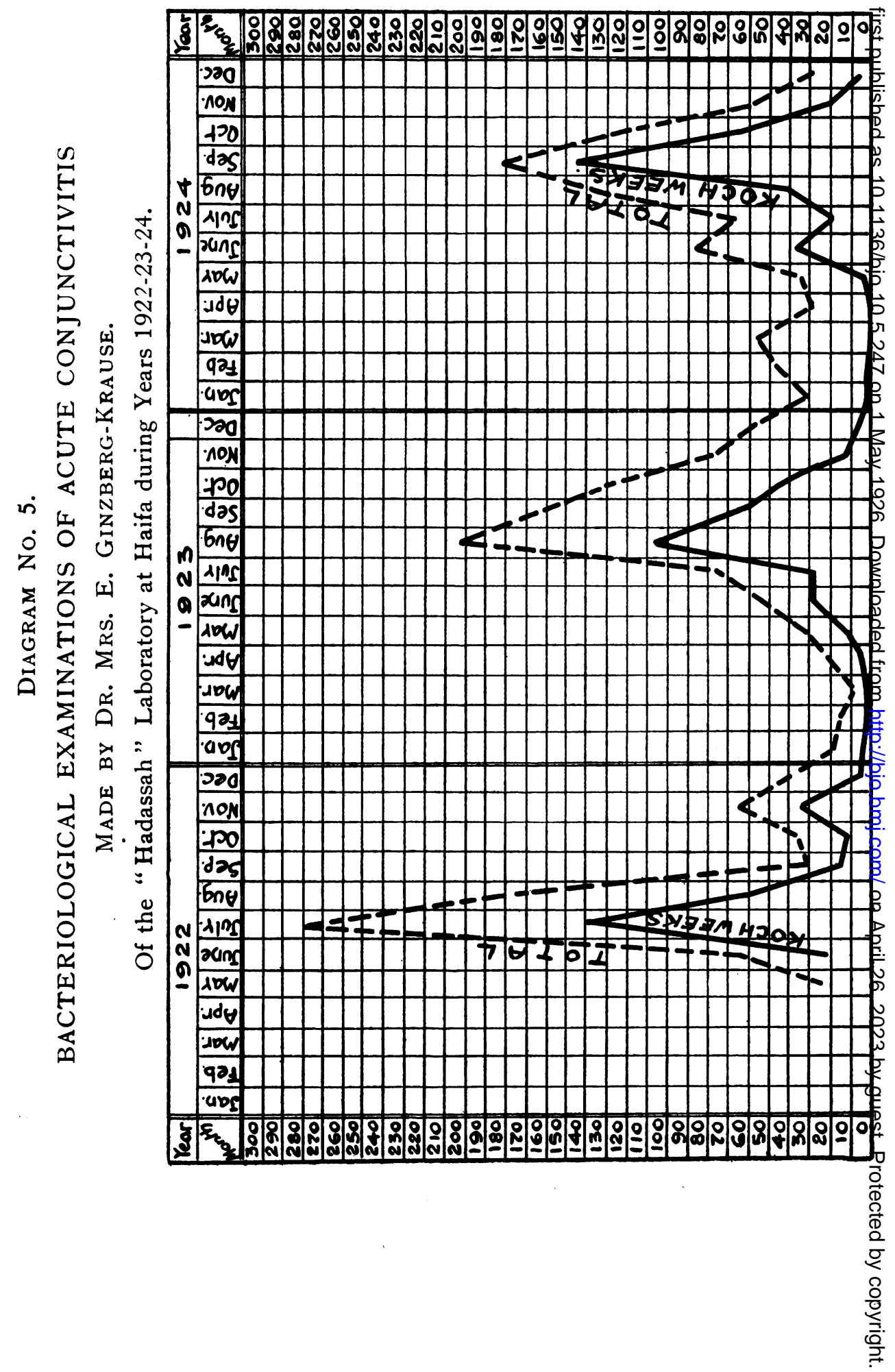


Trachoma in Palestine

\begin{tabular}{|c|c|c|c|c|c|c|c|c|c|c|c|c|c|}
\hline Year & \multicolumn{13}{|c|}{1922} \\
\hline Month & $\stackrel{\text { త్ }}{\sim}$ & i & $\sum^{\pi}$ & 总 & 离 & $\stackrel{\Xi}{\Xi}$ & $\stackrel{2}{\Xi}$ & $\stackrel{\infty}{3}$ & 莒 & ثீ & ż & @̊ & 푱 \\
\hline $\begin{array}{lr}\text { B. Koch-Weeks } & \ldots \\
\text { Morax-Axenf. } & \ldots \\
\text { Pneumococ. } & \ldots \\
\text { B. Xerosis ... } & \ldots \\
\text { Neisser (Gonococ.) } \\
\text { Staphylococ. } & \ldots \\
\text { Mixed infect. } & \ldots\end{array}$ & $\begin{array}{l}- \\
- \\
- \\
- \\
-\end{array}$ & $\begin{array}{l}- \\
- \\
- \\
- \\
-\end{array}$ & $\begin{array}{l}- \\
- \\
- \\
-\end{array}$ & $\begin{array}{l}- \\
- \\
z \\
-\end{array}$ & $\begin{array}{l}- \\
5 \\
2 \\
5 \\
- \\
-\end{array}$ & $\begin{array}{r}22 \\
9 \\
2 \\
1 \\
- \\
-\end{array}$ & $\begin{array}{r}139 \\
2 \\
\frac{2}{25} \\
- \\
-\end{array}$ & $\begin{array}{r}60 \\
4 \\
-7 \\
8 \\
-\end{array}$ & $\begin{array}{l}\frac{14}{-} \\
- \\
-\end{array}$ & $\begin{array}{r}11 \\
-1 \\
2 \\
2 \\
-\end{array}$ & $\begin{array}{r}33 \\
1 \\
1 \\
1 \\
1 \\
- \\
-\end{array}$ & $\begin{array}{r}4 \\
4 \\
-4 \\
1 \\
-\end{array}$ & $\begin{array}{r}283 \\
26 \\
5 \\
45 \\
13 \\
-\end{array}$ \\
\hline Total examination & - & - & - & - & 25 & 65 & 280 & 180 & 30 & 36 & 65 & 39 & 720 \\
\hline Year & \multicolumn{13}{|c|}{1923} \\
\hline $\begin{array}{lr}\text { B. Koch-Weeks } & \ldots \\
\text { Morax-Axenf. } & \ldots \\
\text { Pneumococ. } & \ldots \\
\text { B. Xerosis ... } & \ldots \\
\text { Neisser (Gonococ.) } \\
\text { Staphylococ. } \\
\text { Mixed infect. } & \ldots \\
\end{array}$ & $\begin{array}{l}3 \\
1 \\
1 \\
1 \\
- \\
- \\
-\end{array}$ & $\begin{array}{l}1 \\
2 \\
-1 \\
- \\
-\end{array}$ & $\begin{array}{l}1 \\
1 \\
2 \\
1 \\
- \\
- \\
-\end{array}$ & $\begin{array}{r}4 \\
5 \\
-1 \\
- \\
-\end{array}$ & $\begin{array}{r}11 \\
8 \\
3 \\
1 \\
-\end{array}$ & $\begin{array}{r}28 \\
5 \\
3 \\
5 \\
- \\
-\end{array}$ & $\begin{array}{r}28 \\
4 \\
3 \\
3 \\
- \\
- \\
-\end{array}$ & $\begin{array}{r}106 \\
7 \\
4 \\
11 \\
- \\
1\end{array}$ & $\begin{array}{r}65 \\
5 \\
6 \\
11 \\
1 \\
-2\end{array}$ & $\begin{array}{r}46 \\
3 \\
1 \\
6 \\
8 \\
5 \\
-\end{array}$ & $\begin{array}{c}12 \\
- \\
1 \\
1 \\
3\end{array}$ & $\begin{array}{l}6 \\
7 \\
5 \\
2 \\
-1 \\
3\end{array}$ & $\begin{array}{r}311 \\
48 \\
25 \\
46 \\
11 \\
7 \\
9\end{array}$ \\
\hline Total examination & 18 & 14 & 9 & 20 & 31 & 51 & 76 & 202 & 166 & 127 & 76 & 58 & 848 \\
\hline Yeàr & \multicolumn{13}{|c|}{1924} \\
\hline $\begin{array}{lr}\text { B. Koch-Weeks } & \ldots \\
\text { Morax-Axenf. } & \ldots \\
\text { Pneumococ. } & \ldots \\
\text { B, Xerosis ... } & \ldots \\
\text { Neisser (Gonococ.) } \\
\text { Staphylococ. } \\
\text { Mixed infect. } & \ldots\end{array}$ & $\begin{array}{l}1 \\
-1 \\
1 \\
1 \\
-\end{array}$ & $\begin{array}{l}1 \\
2 \\
5 \\
1 \\
1 \\
3 \\
2\end{array}$ & $\begin{array}{l}- \\
6 \\
1 \\
5 \\
2 \\
-3\end{array}$ & $\begin{array}{l}\frac{6}{1} \\
\frac{1}{-} \\
-\end{array}$ & $\begin{array}{r}4 \\
5 \\
1 \\
2 \\
4 \\
-1\end{array}$ & $\begin{array}{r}38 \\
6 \\
2 \\
8 \\
- \\
5\end{array}$ & $\begin{array}{r}19 \\
5 \\
1 \\
- \\
-2 \\
-\end{array}$ & $\begin{array}{r}40 \\
5 \\
- \\
-4 \\
-\end{array}$ & $\frac{146}{3}$ & $\begin{array}{r}64 \\
3 \\
2 \\
1 \\
7 \\
3\end{array}$ & $\begin{array}{c}21 \\
3 \\
1 \\
5 \\
-\end{array}$ & $\begin{array}{c}5 \\
- \\
2 \\
2 \\
-\end{array}$ & $\begin{array}{r}339 \\
42 \\
15 \\
22 \\
36 \\
6 \\
30\end{array}$ \\
\hline Total examination & 31 & 46 & 54 & 29 & 33 & 87 & 67 & $|137|$ & 181 & 125 & 57 & 29 & 876 \\
\hline
\end{tabular}

GRAND TOTAL FOR 1922/23/24.

$\begin{array}{llllllll}\text { B. Koch-Weeks } & \ldots & \ldots & \ldots & \ldots & \ldots & \ldots & 933\end{array}$

$\begin{array}{llllllll}\text { Morax-Axenf. } & \ldots & \ldots & \ldots & \ldots & \ldots & \ldots & 116\end{array}$

$\begin{array}{llllllll}\text { Pneumococ. } & \ldots & \ldots & \ldots & \ldots & \ldots & \ldots & 45\end{array}$

$\begin{array}{llllllll}\text { B. Xerosis } & \ldots & \ldots & \ldots & \ldots & \ldots & \ldots & 113\end{array}$

$\begin{array}{lllllll}\text { Neisser (Gonococ.) } & \ldots & \ldots & \ldots & \ldots & \ldots & 60\end{array}$

$\begin{array}{llllllll}\text { Staphylococ. } & \ldots & \ldots & \ldots & \ldots & \ldots & \ldots & 13\end{array}$

$\begin{array}{llllllll}\text { Mixed infect. } & \ldots & \ldots & \ldots & \ldots & \ldots & \ldots & 39\end{array}$

$\begin{array}{lllllll}\text { Total examination } & \ldots & \ldots & \ldots & \ldots & \ldots & 2,444\end{array}$ 
B. Koch-Weeks is the chief cause of the acute conjunctivitis, beginning in May, reaching the peak in the hottest and driest months-July and August-and sometimes extending through September. The last rains in 1923 in Haifa were in May and in 1924 in June. The Koch-Weeks epidemic in 1924 was one month later than that in 1923. With the onset of cooler and rainy weather the Koch-Weeks epidemic ceases. At the end of the Koch-Weeks epidemic a small epidemic of gonococcic (Neisser) infection breaks out. There are also mixed forms of infections-Koch-Weeks and pneumococcus; Koch-Weeks and Morax-Axenfeld; Koch-Weeks, Gonococcus-Neisser. These last forms of conjunctivitis (there were ten cases from Nazareth and Tira in 1924) are usually accompanied by corneal destruction (ulcus corneae and prolapsus iridis).

The following table represented in Diagram No. 6 gives the bacteriological findings in the acute and chronic conjunctivitis in Haifa during 1922, 1923, and 1924 :

$\begin{array}{lllllrlr} & & & & \text { Cases. } & \text { Per cent. } \\ \text { Bac. Koch-Weeks } & \ldots & \ldots & \ldots & 933 & = & 38.2 \\ \text { Bac. Morax-Axenfeld } & \ldots & \ldots & \ldots & 116 & = & 4.7 \\ \text { Bac. Pneumococ. } & \ldots & \ldots & \ldots & 45 & = & 1.9 \\ \text { Bac. Xerosis } & \ldots & \ldots & \ldots & \ldots & 115 & = & 4.6 \\ \text { Gonococ.-Neisser } & \ldots & \ldots & \ldots & 60 & = & 2.5 \\ \text { Staphylococ. } & \ldots & \ldots & \ldots & \ldots & 13 & = & 0.5 \\ \text { Mixed infection } & \ldots & \ldots & \ldots & \ldots & 39 & = & 1.6 \\ \text { Negative ... } & \ldots & \ldots & \ldots & \ldots & 1,123 & = & 46.0 \\ & & & & & & \\ & & & & & & \end{array}$

These forms of acute conjunctivitis, besides causing various corneal complications when trachomatous infection is present, also serve as a factor in damaging the conjunctiva and facilitating the penetration of the trachoma virus.

In addition to the climatic conditions of Palestine facilitating the spread of trachoma, there are other factors acting as an obstacle in the fight against trachoma. One of these factors is either the shortage of water (in Jerusalem and the Southern portion of Palestine) or the limited use of water because of the distance of the houses from the source of water supply.

On the basis of what has been stated above, considering for each place the factors serving as a cause of trauma to the conjunctiva, i.e., the number of cloudless days, temperature, amount of rainfall, the character of the soil, house accommodation, the standard of living of the population, one is able with relative 


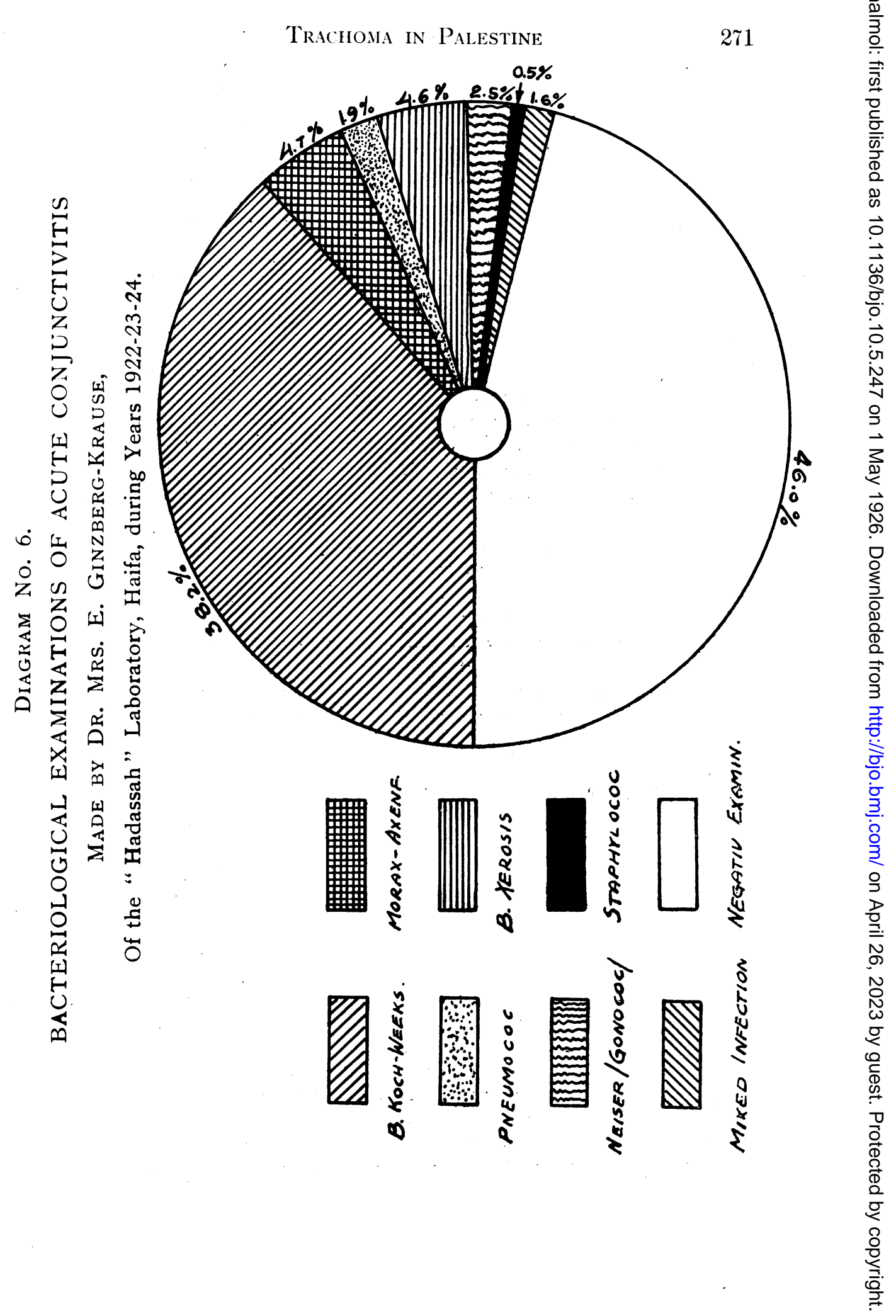


certainty to explain why there is more trachoma in the south and less in the north of Palestine. First of all, in the north there is less limestone dust, and fewer sand dunes, there is a larger supply of water, greater rainfall, and a less crowded population. In Acre which is only ten kilometres distant from Haifa, the percentage of trachoma among the school children is only half of that found among the school children of Haifa. Other conditions being equal, Acre has a good water supply, while Haifa has not. Housing conditions are also better than in Haifa. Gaza which, like Haifa, is on the sea level, but lies in the southern border of Palestine, has much more trachoma than Haifa. The explanation for this can be found in the fact that Gaza has more cloudless days, that there are $\mathbf{4 1 8}$ millimetres of rainfall per annum, while in Haifa there are 608. Gaza has more sand dunes and dust, and it is subject to the action of the prevailing winds from Sinai desert. The reason for the large prevalence of trachoma in Tiberias can be found in the facts that the annual rainfall is 450 millimetres, that during the four or five summer months there are no rains at all; the average atmospheric temperature is three to four. degrees higher, and the number of cloudless days larger than in the coastal plain; in short, in Tiberias there are at play a larger number of factors that cause trauma to the conjunctiva and create favourable conditions for the penetration of the trachoma virus. The attached table gives the amount of rainfall, cloudless and mean temperature for each month of the year in Haifa, Sarona, Gaza, Nazareth, Jerusalem, Hebron, Tiberias. This table is taken from the "Annual Review of the Agricultural Situation in Palestine," $1922^{(19)}$ (see Table III).

\section{III.-Means of Combating Trachoma in Palestine}

As previously indicated the incidence of trachoma in Palestine is very high and the great question is how to fight against the disease among an ignorant population. There can be little doubt that a general improvement in education and the conditions of life in general will be one of the greatest aids towards its eradication. As an example I may state the fact that among the children at the better class Jewish schools there is little or no trachoma. Among the pupils of the Jerusalem "Gymnasium" during the year 1923 there was not a single case of trachoma while among those of the "Real" school at Haifa there was only one (less than 0.5 per cent.). As has been noted in the review of literature on the subject the same low incidence was noted in the "Gymnasia" of Jerusalem and Jaffa in the years 1913-1914. Trachoma is found in those Jewish schools where the children of the poorer classes are educated and who come from homes where the standard of 
Trachoma in Palestine

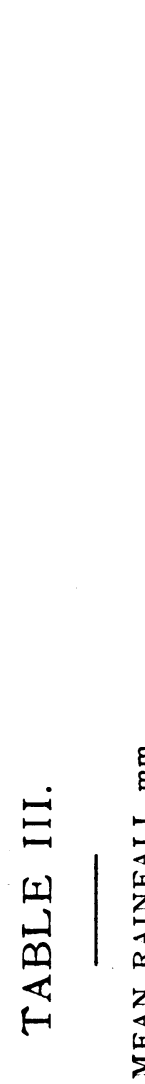

要

岁 $\mid$ b. $\rightarrow \quad$ 은

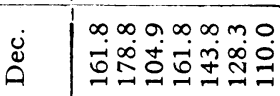

> $90000-10$

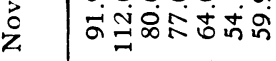

ن $\quad$ o o o a n ino

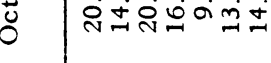

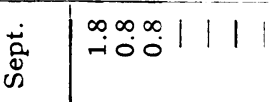

$\sum_{4}^{\infty}|1| 1|1|$

$\equiv \mid 111111$

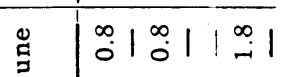

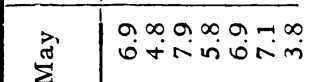

- agagara

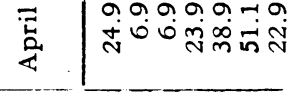

ป $\infty \infty \infty \infty 909$

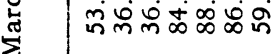

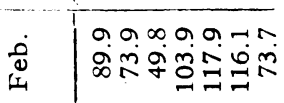

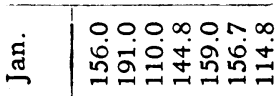

$\dot{n}:=::=:$

ㅁㅇㅇ음ํํ요

$\vdots \vdots \vdots \vdots \vdots \vdots \vdots$

ن

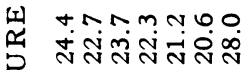

$+\infty$ in 000 .

तंจंतี

कmmm

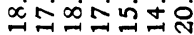

z

$\infty \sin \infty+0$

n่าม

Nom $\infty$ ON

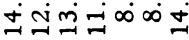

Non $\ln \infty 0$

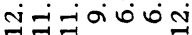

○் Nम

ค

$0,0+\operatorname{mon} a n$ minimintU

Nonmant mincitimin

nmmatrm trminging

$0 a-0$ on 0

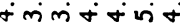

No nond

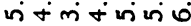

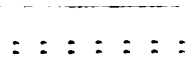

응으늉유유

$:::=::=$

응ㅇ음유유요

¿ : $\vdots \vdots \vdots \vdots \vdots$

¿ $\vdots \vdots: \vdots \vdots \vdots$

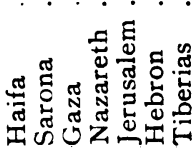


education and habits of life are low and who in general live under conditions similar to the Arab population. The problem of the moment is to find a rapid and satisfactory method of dealing with trachoma under these existing unfavourable conditions.

\section{The Treatment of Trachoma among School Children as a means of Combating the Disease}

As a result of the work of the Hadassah Medical Organization in Jewish schools during the past five years trachoma has fallen from 40.6 per cent. to 15.3 per cent., and in the work of the Government in Government schools the figure has fallen from 74 per cent. to 62 per cent. We can therefore fairly assume that this method is showing success. The treatment in schools is important not only from the point of view of the treatment per se and the fact that the child is constantly under medical supervision, but from the fact that he learns early in life the importance of the hygiene of his eyes and carries into the home the principles instilled into him with regard to the care of his eyes. I have frequently seen cases at our dispensary where children have brought their parents for ophthalmic treatment. The school is thus not only a centre of education in its narrower sense, but a means of disseminating the doctrine of hygiene and health throughout the land. This is particularly important in the case of the Arabs, the bulk of whom are illiterate or nearly so and have no ideas whatever of hygiene in general, let alone eye hygiene. Working on these lines the first thing to be done is to increase the number of schools as far as possible and endeavour to get as many of the population as possible in their early youth. Trachoma can thus be dealt with in its early stages, before it begins to give rise to complications of the eyelids and eyelashes (entropion and trichiasis) or of the cornea (pannus, ulcers), and as a further consequence maculae and leucomata which bring about diminution of visual acuity, and thus render the sufferer a less useful member of the community.

The following figures indicate the great importance of treating trachoma efficiently in its early stages :

\begin{tabular}{c|c|c|c|c|c|c}
\hline Year & $\begin{array}{c}\text { No. of Children } \\
\text { examined }\end{array}$ & $\begin{array}{c}\text { Entropion and } \\
\text { Trichiasis }\end{array}$ & Pannus & $\begin{array}{c}\text { Macula } \\
\text { Corneae }\end{array}$ & $\begin{array}{c}\text { Staphyl. } \\
\text { Corneae }\end{array}$ & $\begin{array}{c}\text { Phthisis } \\
\text { Bulbi }\end{array}$ \\
\hline $1918-1919$ & 8,395 & 123 & 40 & 99 & 14 & 31 \\
$1923-1924$ & 13,470 & 6 & 18 & 49 & - & - \\
\hline
\end{tabular}

The above figures show the complications affecting the eyelids and corneae of children attending Jewish schools in the years 19181919 and 1923-1924. It is thus seen that entropion and trichiasis 
can be reduced almost to a minimum. Pannus during five years has been reduced more than 50 per cent. and maculae and corneal leucomata by 50 per cent. More than half of the 49 cases of macula corneae are a legacy from the days of the war, and the remainder are the result of affections of the cornea following severe conjunctivitis contracted prior to school age. Staphylomata and phthisis bulbi have disappeared. By systematic treatment in the schools not only has trachoma been reduced but also all other affections of the conjunctiva (Shimkin $\left.{ }^{(14)}\right)$.

The undernoted figures are taken from the Government report for the year $1923^{(20)}$ :

\section{NUMBER OF SCHOOL CHILDREN AND THEIR DISTRIBUTION IN TOWNS AND VILLAGES} (URBAN AND RURAL AREAS.)

\begin{tabular}{|c|c|c|c|c|c|}
\hline & & $\begin{array}{l}\text { No. of } \\
\text { Schools }\end{array}$ & $\begin{array}{l}\text { No. of } \\
\text { Boys }\end{array}$ & $\begin{array}{l}\text { No. of } \\
\text { Girls }\end{array}$ & $\begin{array}{l}\text { No. of } \\
\text { Teachers }\end{array}$ \\
\hline $\begin{array}{c}\text { Government Schools- } \\
\text { Towns }\end{array}$ & $\ldots$ & 47 & 5,298 & 2,756 & 332 \\
\hline Villages & $\ldots$ & 267 & 10,748 & 529 & 340 \\
\hline Non-Government Schools & $\ldots$ & 397 & 19,657 & 14,479 & 1,701 \\
\hline Totals $\ldots$ & $\ldots$ & 711 & 35,703 & 17,764 & 2,373 \\
\hline
\end{tabular}

According to the census of October, 1922, the total population of Palestine was $\tau 5 \%, 182$. The total number of school children is 53,467 which is 7 per cent. of the total population. The most important fact which the above table brings out is that of the total of 314 Government schools only 47 are in the towns. This is from our point of view most satisfactory because it is in the villages that the greater part of our endeavour must lie. If all the village schools of the Government are not all that could be desired from the point of view of hygiene they are at least infinitely better than the miserable hovels of the villagers. According to the census referred to above the whole of the rural population of Palestine (i.e., village population) was in $1923,389,534$, and in village schools there were 11,279 pupils, i.e., only 2.9 per cent. The total number of girls was only 529. This is due to the fact that the Arab population in the villages care very little about female education. The total number of children in Palestine in the age group 5 to 15 years is 154,980 of which number $85, \pi$, 78 are boys and 69,202 are girls. The total number of children at school is 
53,467 ; hence there is 34 per cent. of the children in the age group 5 to 15 years at school. The schools thus constitute a large eye dispensary and one where the attendance is more or less regular. We can therefore now see that : life.

(1) Trachoma in Palestine is a disease contracted in very early

(2) Treatment of trachoma in its early stages prevents those complications of the lids and cornea which endanger the vision.

(3) Trachoma in its early stages can be cured rapidly by medical or surgical treatment.

(4) Schools form by far the best centres for treatment, supplying as they do a large complement of patients who can be kept under constant supervision.

(5) The value of these school clinics is enhanced by the fact that they disseminate ideas of hygiene among the population.

Therefore the increase in the number of schools, particularly in the villages, combined with systematic treatment of the children attending them, appears to be the best means of dealing with trachoma in Palestine under the present conditions. This is particularly applicable to the Arab population.

\section{Ophthalmic Treatment available for the General Public in Palestine}

At present eye treatment is rendered by certain Government clinics and various voluntary organizations. According to the Government Report for the year $1923^{(20)}$ the Voluntary Dispensaries dealt with a total of 203,311 patients of whom 51,060 were eye cases. During the same period the Government Dispensaries handled 67,634 patients of whom 17,291 were eye cases. Thus out of a total of 270,945 patients there were 68,351 cases of eye disease, i.e., 25.2 per cent. of the total patients or 9 per cent. of the total population.

Special eye treatment on a large scale is rendered by the following institutions :

(1) The British Ophthalmic Hospital (Order of St. John) at Jerusalem, which has fifty beds for eye cases and dealt during 1923 with a total of 14,537 cases.

(2) Hadassah Medical Organization, which has twenty beds available for eye cases and dealt during the same period with 13,519 cases at its various clinics (Jerusalem, Tel-Aviv, Jaffa, Haifa, Tiberias, and Hehron). 
(3) St. Louis (French) Hospital which dealt with 8,053 cases during the same year.

The total number of Voluntary Dispensaries in Palestine which provide special facilities for eye treatment is 30 , of these 8 are in Jerusalem, 2 in Hebron, 2 in Bethlehem, 7 in Jaffa, 1 in Gaza, 4 in Haifa, 1 in Nablus, 2 in Nazareth, 2 in Tiberias and 1 in Safed. The Government has ophthalmic clinics in Jerusalem, Hebron, Ramallah, Beersheba, Jaffa, Ramleh, Gaza, Beisan, Nablus, Haifa, Acre, and Tulkarem. It is of interest to note that the Government Clinic at Nablus was visited by nearly 10,000 eye cases during the year 1923 alone. In addition during the years 1919 to 1923 a very large amount of eye treatment was rendered to the Arab population in the villages by the Government Travelling Ophthalmic Hospital. It is greatly to be regretted that this hospital had to be closed down for lack of means to support it. It existed for 31 months and dealt with 14,801 patients of whom 64.2 per cent. were infected with trachoma. There is only one private ophthalmic hospital : this is in Jerusalem and has 30 beds. The total nmber of ophthalmic specialists in the year 1923-24, i.e., physicians dealing exclusively with ophthalmic cases is 17 . Of these 7 are in Jerusalem, 6 in Tel-Aviv (Jaffa), 2 in Haifa and vicinity and 2 in Upper and Lower Galilee districts.

\section{Method of dealing with Trachoma among Adult Population}

Dealing with children in schools has been found the best way of handling trachoma in their case. A constant attempt to improve the general sanitary circumstances of the dwellings and surroundings of the population appears to be the best way of approaching the matter in the case of the adult population. Every endeavour must be made to combat flies which are the chief means of disseminating the trachoma infection (Nicolle-Guénod ${ }^{(13)}$, David ${ }^{(5)}$ ) and acute conjunctivitis (Shimkin ${ }^{(14)}$ ). The population must be made aware that trachoma is a very contagious disease and information as regards prophylaxis must be spread. As a very large number of the Arab population are illiterate this method is difficult. The use of dark spectacles is also useful as a protection from dust and glare (Fuchs $\left.{ }^{(16)}\right)$.

The foregoing are only prophy,lactic measures, however, and bring no relief to the three-quarters of the population that are already infected with trachoma. For these treatment is necessary, and for this purpose more ophthalmic specialists, hospitals, and dispensaries are required. Seventy beds for ophthalmic cases is too little in a population of 800,000 people. An increase of the number 
of physicians with a knowledge of external eye diseases and capable of making an accurate diagnosis is much required. In this connection Dr. J. Strathearn of the British Ophthalmic Hospital in Jerusalem is giving special courses of instruction in eye diseases to both doctors and nurses of the Government service. The Hadassah Medical Organization is also specially training doctors and nurses who are subsequently sent to the Jewish colonies all over the country. Municipal and village authorities must also be interested in the work. The efforts of the Government and voluntary institutions combined with an interest and help on the part of local authorities, better education, improved sanitary conditions in general and a general improvement in the standard of living cannot fail to bring about a large decrease in eye disease in general and trachoma in particular. It is also of importance to mention that the ignorance of the Arab village population serves as a great hindrance in the fight against trachoma in Palestine. The village Arab consults a physician only after serious complications have set in. The usual question of the sick man or woman is whether it is permissible to wash the hair and eyes at least once a week. It seems that the people have learned through experience that water or washing, in common basins serves as a medium of transmission of trachoma or other eye infections. It is also necessary to mention the custom among the people to receive treatment from the hands of the village "healer," to place faith in the wearing of a "charm" (Canaan, T. ${ }^{(15)}$ ) as a means of preventing eye infections. They also paint their eyelashes (with "Kohl asmar"*) not only for cosmetic purposes but also with the idea of preventing eye infections; this paint is smeared on with a stick used by all, thus helping to spread any infection which may exist. A popular method of treating eye diseases is by burning the temples and neck with a heated iron, or blood letting by making incisions on the neck, hands, and legs, packing these wounds with dirty rags or beans or peas in order to produce suppuration and thereby relieve the eye trouble. One has frequently great difficulty in convincing the patient that he must remove this drain from the sloughing wound.

Vast improvements, however, cannot be hoped for at once; it must be remembered that other countries affected with trachoma have spent a large amount of time and money before the disease was reduced to any great extent, or eliminated.

In this respect I may quote some figures from Belgium showing the decline of trachoma in the army (Paparcone $\left.{ }^{(12)}\right)$.

\footnotetext{
* This is prepared by mixing powdered lead sulphide with oil until a paste is formed. This is heated thoroughly until almost dry and is then painted on the borders of the upper and lower eye lids just above the eye lashes.
} 


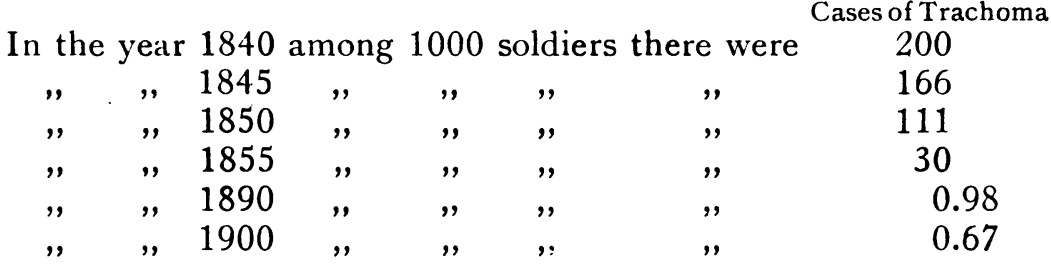

It will be seen from this that it took 60 years of constant work to effect the reduction.

In spite, however, of the immensity of the task before us in Palestine, it is hoped that the measures already indicated combined with a better economic situation and the improvements in the standard of life which must inevitably follow, will bring about a very great decrease in trachoma in that country.

\section{REFERENCES.}

1. German, T.-Augenärztliche Beobachtungen in Syrien und Palaestina, speziell über das Trachom in diesen Ländern. Centralbl.f.Augenheilk., p. $386,1896$.

2. Krinkin. - Trachoma in the Jewish Schools of Palestine and the Means of Combating it. Jaffa, 1913 (Hebrew.)

3. Auerbach, E.--Deutsche Med. Wochenschr., No. 37, 1913.

4. Feigenbaum, A.-Ansteckende Krankheiten Palaestinas und ihre Bekämpfung. Jerusalem. Erster Bericht, 1913.

5. Idem.-Bericht ueber die erste Trachomkonferenz der juedischen Aerzte Palaestinas. Jerusalem, 1914 (Hebrew.)

6. Friedenwald, H.-The Ophthalmias of Palestine, Baltimore, Md. Reprinted from Amer. Ophthal. Soc. Trans., 1915.

7. Telavivi, A.-Das Trachom in Palaestina. Arch. f. Augenheilk. B. LXXXV. H. 1/2, 1918.

8. Shimkin, N.-Trachoma in the Jewish Schools of Jaffa (Hebrew). Michtaw Choser, No. 8, I-III, 1922.

9. Wibaut, P., and Smit, W. H. -Ann. d'Ocul, September, 1924.

10. Axenfeld, Th.-Die Aetiologie des Trachoms. Nach einer Bearbeitung für den XII Internationalen Ophthalmologenkongress, Jena, 1914.

11. Stanculeanu, Michail.-Das Trachom nach dem gegenwärtigen Stande der Forschung, 1912.

12. Paparcone, E.-- Il Tracoma e sue complicazioni, Milano, 1922.

13. Nicolle, Ch.-Etat de nos connaissances d'ordre experimental sur le trachome. Extrait du Bulletin de l'Institut Pasteur, Tome XIX, Décembre 30, 1921.

14. Shimkin, N.-Les maladies des yeux à Caiffa (Palestine.) Ann. d'Ocul., Décembre, 1924.

15. Canaan, T.-Aberglaube und Volksmedizin im Lande der Bibel. Abhandlungen des Hamburgischen Kolonialinstituts. Bd. XX., 1914.

16. Fuchs, E.-Beleuchtung und Auge. Wien. Med. Wochenschr., No. 32, 1921.

17. Ticho and Kligler.-Trachoma in Palestine. Lancet, pp. 706-707, September 30, 1922.

18. Scheffer.-Russky ophthalmologechesky Jl., No. 7, p. 659, 1923.

19. Department of Agriculture and Fisheries, Palestine. A review of the Agricultural Situation in Palestine. By E. R. Sawer, Director of Agriculture.

20. Government of Palestine, Annual Report of the Department of Health for the years $1921,1922,1923$. 